\title{
Ashé-Diasporan Spirituality in Carlos Wilson's Los nietos de Felicidad Dolores
}

Oor individuals of African ancestry, liberty not
only means freedom from physical restraints such as chains, but also equality, and the freedom to express traditional spiritual practices. Carlos Guillermo Wilson (Cubena) is one of Panama's first novelists to integrate elements of Afro-Caribbean spirituality in a positive manner to counter negative attitudes toward African-inspired cultural expression. His novels, Chombo (1981) and Los nietos de Felicidad Dolores (1991), and his numerous collections of short stories and essays focus on the historical tensions among the nation's black communities. His literary works look at racism against blacks throughout the world, while highlighting injustices waged toward Afro-Antilleans in Panama, who have been referred to derogatorily as chombos, cocolos, and pichones. In both novels, Cubena projects an aggressive tone against Panama's Colonial Black population, which historically has looked down upon their Antillean cohorts.

The word chombo refers to English-speaking West Indians from Jamaica or Barbados. Cocolo and pichón historically have been despective terms. Cocolo originated in the Dominican Republic and is used in the Spanish-speaking Caribbean to describe emigrants from St. Kitts, Nevis, and Anguilla to work on the sugar plantations from the 1880s to the 1920s (Watson 155). Pichón refers to individuals of Haitian or West Indian ancestry (Watson 155). One of the tensions that is most evident in Los nietos and Chombo is the antagonism that exists between Panama's two populations of African heritage: Antillean and Colonial Blacks. The polarization between the two groups is based on perceived differences of ethnicity. The Antillean Black population has traditionally been forced to adapt and survive in a country, which historically has opposed their presence and cultural expression. The Antillean immigrant population has been considered inferior to other immigrant groups thus preventing them from fully enjoying the political, social, and economic freedom offered to other immigrant populations. Antillean Blacks have been, and continue to be, systematically despised even though many of them and their ancestors have dedicated their lives, labor, and resources to the development of the economic and cultural foundation of Panama. Cubena's novels thus play an important role in highlighting this overlooked group and acknowledging in literature an Afro-Caribbean cosmovision which will be referred to as AshéDiasporan literary perspective in this study.

This study will focus on Los nietos de Felicidad Dolores and the manner in which the work serves as an example of Ashé-Diasporan literature. The first part of this term, ashé (ache), is an invisible -yet palpable- creative energy. Santero Ócha'ni Lele connects the term with the orishas or saints in Santería: "Each orisha is a living, spiritual personification of limited aché. (a word that loosely translates into 'power, grace, and life'). The ache of an orisha depends on the aspects of Olódumare from which it was spawned" (1-2). Afro-Hispanic spiritual scholar, Martha Moreno Vega, acknowledges the creative power of ashé within the Caribbean when she writes the following: "The more than thirteen million Africans who survived the Middle Passage carried with them the creative impulse that continues to weave through the aesthetic vision and expressions of African descendants" (46). This term will describe literature produced in the African Diaspora that acknowledges elements of West African spirituality and influenced by this cultural aesthetic. Los nietos de Felicidad Dolores includes African-oriented imagery and rituals to acknowledge African-influenced traditions thus serving as a form of cultural resistance. The orishas from the pantheon 
of African saints and the symbol of the tortoise establish a connection between the characters and an African worldview. The novel destroys the myth of classical mythology and Western Christianity being the only approach to understand human existence and life. Los nietos is filled with numerous examples of African myths and it is through griot figures that the reader is able to appreciate this cultural perspective. The central griot, Felicidad Dolores, pays homage to African elder tradition by reflecting them as the heart of the community/family. ${ }^{1}$

The novel counters the historical perception of African-inspired spirituality being inferior. Cubena is following a literary trajectory started decades earlier by the study of Afro-Cuban faith practices by Cuban anthropologist/ethnographer Fernando Ortiz and continued by fellow Cuban scholars such as Miguel Barnet, Lydia Cabrera, Alejo Carpentier, Rómulo Lachatañeré, and Nancy Morejón. This tradition of Ashé-Diasporan literature has continued in the works of non-Cuban writers such as Manuel Zapata Olivella, Mayra Santos-Febres, and Quince Duncan to name a few. This form of literature focuses on the Black experience in the Diaspora and acknowledges spiritual traditions that once were considered shameful and satanic. The novel illustrates the destructive force of prejudice among individuals of African descent in a nation that favored such tensions as a way to conquer and divide the oppressed. Cubena offers an Ashé-Diasporan perspective that reflects historical events and Africaninspired mythology woven together with his own literary creativity.

One of the characteristics that is important in this novel is the way that it reverses the negative portrayal of West Indians that colored early twentieth-century Panamanian literature and culture. Cubena uses an inversion technique to erode negative stereotypes traditionally associated with West Indians and replaces them with positive qualities traditionally associated with the mestizo and Afro-Colonial community. The novel is filled with details of PanAfrican culture, history, and literature. The setting spans from fifteenth-century Spain, the Middle Passage, to the late twentieth century.

Cubena is a descendant of Jamaicans who came from Maroon Town Jamaica, St. Kitts, Cuba, and Grenada. Critics who have studied his works include Richard Jackson, Elba Birmingham Porkney, Marvin
Lewis, Ian Smart, and Sonja Stephenson Watson. Cubena is a proud descendant of West Indians and uses the negative treatment of West Indians to fuel his writing. In The Politics of Race in Panama: Afro-Hispanic and West Indian Literary Discourses of Contention, Watson concludes that there has been a lack of acknowledgement of his work within the nation of Panama because his works destroy the national myth of racial harmony (72). While research has acknowledged African elements within his literature, there has been no in-depth scholarship that analyzes the African-inspired spiritual elements within Los nietos de Felicidad Dolores.

In an unpublished biography, Cubena explains how he weaves history into his texts and states his objective in the following manner: "Escribo para denunciar la actitud, desgraciadamente, internacional de desdén, rechazo y odio que, como un diluvio, inundan, ad nauseam, a los de asendencia africana" (Unpublished Autobiography 22). ${ }^{2}$ The author focuses on revealing racist and stereotypical-thinking, which has caused descendants of Africa in the Diaspora to collectively suffer and inflict pain upon one another as result of interethnic tensions (Watson 86). When asked about his own literary antecedents in an interview with Birmingham-Pokorny, Cubena responds with the name of Joaquín Beleño, indicating that Beleño's narrow literary perspective motivated him to write: "Every time I read any of his trilogies, I become so angry because of the way he has portrayed 'Chombos' -Afro-Hispanics-in his works" ("Interview" 128). He believed that Panamanian Joaquin Beleño's novels -Los forzados de Gamboa (Gamboa Road Gang) (1960), Luna Verde (1950), and Curundú (1955) fail to present Antillean Blacks in a positive and accurate manner. In a 1998 interview, a more settled Wilson would praise Beleño for his Trilogía canalera (Soley 69). Cubena refutes Beleno's portrayal by exposing injustices against Antillean Blacks by members of the Panamanian leadership structure, which have consistently discounted Antillean Blacks. One of the ways that he acknowledges African identity is by focusing on African-inspired spirituality.

African-influenced spiritual practices have historically been an important agent in social and political change throughout the African Diaspora. While the dates may differ among nations, revolts were planned within communities under a colonial 
hegemonic system. Frequently, these elements united participants and allowed them to fight for their freedom, individual rights, and self-determination. Many of these leaders have become mythical national figures. ${ }^{3}$

The slave rebellion that made the greatest impact in the Caribbean was the revolution mounted by rebel slaves in the French colony of St. Dominque in 1791. This highly-organized revolt took advantage of the turmoil in the colony caused by the revolution in France that broke out two years earlier. Led by Toussaint L'Ouverture, 500,000 enslaved Blacks in St. Dominque defeated the armies of three major European powers: France, Spain and Britain. Mackandal and his position as a Houngan in the Vodun faith tradition and the use of the drum as a means of communication led thousands of slaves to resist their French oppressors in $1791 .{ }^{4}$

The Haitian Revolution is a vivid example of a collective group being unified by African-influenced spiritual culture. Such spiritual inspiration has encouraged oppressed people to risk their lives to gain freedom despite mechanisms such as the Code Noir which was established to control their black cultural expression in Public. ${ }^{5}$ After the success of the Haitian Revolution (1791-1804), other nations in the Caribbean became conscious of the importance of restricting social activities within black communities.

Cubena's use of literature to promote social change corresponds with Frantz Fanon and his theory of intellectual development of the native writer in The Wretched of this Earth (1961). In the first phase, the writer demonstrates his assimilation to the values of the "dominant" culture. The next stage is described in the following manner:

In this second phase we find the native is disturbed; he decides to remember what he is. This period of creative work approximately corresponds to the immersion, which we have just described [demonstrating that he has assimilated the values of the dominant culture]. But since the native is not a part of his people, he only has exterior relations with his people, he is content to recall their life only. Past happenings of the bygone days of his ch[i] ldhood will be brought up out of the depths of his memory; old legends will be reinterpreted in the light of a borrowed estheticism and a conception of the world which was discovered under other skies. (222)

Fanon notes that the native intellectual sees the value of documenting past communal memories, both good and bad. The native writer is able to establish a base on which to build a foundation that supports his peers and their cultures. In the third phase, the writer attempts to motivate compatriots into social change through literature. It is during this point that the writer produces fighting literature or revolutionary literature. (Fanon, The Wretched 222) It is this form of fighting literature that makes Cubena's novel so revolutionary in reflecting elements of Africaninfluenced spiritual practices.

Fanon concludes that at times this literature is produced "just-before-the-battle" and is dominated by humor and by allegory. This element of the novel has been addressed in the article "Humor and Satire: Ammunition in Carlos Guillermo Wilson's Resistance Novel Chombo," (Edison 2000). Fanon theorizes that this tone is symptomatic of a period of distress and difficulty, where the native writer experiences death and disgust against the injustice that surrounds him/ her. He notes that while the native writer pushes himself and his people forward, at the same time he mocks the dominant population (222). The novel characterizes the non-Afro-Antillean descended population, with disgust, shock, sarcasm, as well as a mocking tone of laughter. To better understand how the spiritual elements appear in the novel, it is important to briefly survey Afro-Caribbean spiritual elements.

Similarities between European and African belief systems aided in the cultural syncretism between Christianity and African-oriented faith practices known as orishas in Lucumi culture. ${ }^{6}$ Even the name "Santería," derived from the Spanish word "santo" borrowed from Catholicism, meaning worship of the saints. Santería also adopted the terminology from the Catholic Church institution of compadrazgo, making a believer a godchild (ajihado / ajihada) of the primary orisha and spiritual mentor. In this capacity, the believers are the godchildren of the santero or intermediaries who spiritually protect and guide them. Traditionally, Catholic and African religions both have employed countless objects and symbols in ceremonial activities. In modern Afro-Caribbean spiritual ceremonies, alongside traditional African symbols, one can find many items representing Western religious beliefs, such as the iconic 
representations of Catholic saints, the crucifix, and prayers from the Bible. The saints venerated by the Roman Catholic Church easily corresponded with the structure of the pantheonic orishas in Santeria. Many Afro-Cuban deities have a Christian avatar that bears the name of a Catholic saint. Because of this transcultural integration, African slaves could often continue to practice their own traditional practices while appearing to celebrate the religion of their masters. Despite parallel similarities, Africaninfluenced spiritual practices have been considered backwards, demonic, and heathenish by many, including individuals of African ancestry. Many of these negative attitudes are unfounded and only exist as result of racism against all forms of African cultural expression.

Afro-centric spiritual practices are similar to Judeo-Christian beliefs through the use of myths to explain great spiritual forces, the origin of humanity. African-inspired spirituality plays an important role in Los nietos by reflecting the ontology of a community that has been scattered throughout the Western Hemisphere and maintained contact with powerful African-inspired deities practice, and sacred rituals. Each path of Afro-Caribbean religion has a name for its higher forces, such as orishas, ochas, dioses, santos, espiritus, mpungas, loas, or mystères. The Santería Pantheon of Saints consists of seven great deities, which are known as Las Siete Potencias Africanas. In Santería: African Magic in Latin America, Migene González-Wippler offers a list of details associated with deities such as their areas of specialization, their attributes, and their Catholic counterparts: Changó - Santa Bárbara / Eleggúa - Holy Child of Atocha / Obatalá - Virgin of Mercy / Oggún - Saint Peter / Orúnla - Saint Francis of Assisi / Oshún - Virgin of Caridad del Cobre / Yemayá - Virgin of Regla (107-125). Scholars familiar with Afro-Caribbean spirituality cannot overlook the irony that in the novel, immigrants from the West Indies would be connected with elements of Santeria, since they have traditionally been protestant as result of British colonization. These cultural differences and tensions are described by Watson in the following manner:

While Afro-Hispanics have 'assimilated,' older generations of West Indians have not, and they continue to assert their black consciousness over their Panamanian nationality. This conflict has strained race relations between West
Indians and Panamanians because the former vehemently challenge the racial (Hispanic), linguistic (Spanish), and religious (Catholic) components of Panamanian nationality (2).

Cubena used artistic license as a way to integrate elements of Santería with the West Indian population as a way to project a unified Afro-Diasporan worldview in the novel. The first manner in which the novel topples the traditional perspective toward Christianity is by presenting specific characters, mostly Antillean Blacks and their descendants, as being successful and positive while the Christian Colonial Blacks are presented as being dysfunctional, mentally unstable, and malevolent.

The novel begins at the J.F.K. International airport (New York City, New York) during a snowstorm, caused by a nuclear accident. The family awaits their flight to Panama to witness and celebrate the signing of the Carter-Torrijos Treaty in 1977. Matriarch Felicidad Dolores and her extended family reminisce about their rich history and share tales about acts of racism that have endured as they await the arrival of other members of the family. They are further linked as they search for the origin and definition of the mysterious word sodinu. Each time a new member of the family arrives from different parts of the Americas, he or she is asked about the meaning of the word.

Felicidad Dolores is connected with the Yoruba orisha Yemayá who is considered to be Goddess of the sea and mother of humankind. This parallel is underscored by making reference to the matriarch and the color blue, the color associated with Yemaya and the ocean. She is described as always wearing blue: "Más importante aún, la señora Felicidad Dolores llamaba la atención, sobre todo, porque siempre lucía ropa azul; todos los martes, a las tres en punto de la tarde, se bañaba con agua de mar..." (Wilson, Los nietos 13). Later there is reference to her carrying a blue handkerchief (63) and sitting in a blue chair (68). Her address in Panama is the fifth of May, the same date in 1914 when El Polvorin occurred. One of the most important details of this tragic event was the manner in which it reflects unity and collective support. A large fire broke out in a building that housed the United States gunpowder reserve. The fire claimed the lives of six Panamanian firefighters and serves as an example of the community unifying to avert a crisis that could have been much worse if it 
had not been for brave firefighters and civilians.

The elements of African-influenced spiritual culture also appears among the matriarch's many distinguished adopted grandchildren. Triunfo Guerrero is a cultured gentleman who bears a powerful name and is described as being the son of a santero or priest in Santería:

Triunfo Guerrero, hijo de santero, comentó que en cuando a la tormenta era evidente la furia del orixá Changó y su esposa Oyá, la orixá africana de las tempestades. Y, luego, agregó que posiblemente, lo del accidente nuclear era otra travesura del orixá Elegguá. No obstante, Triunfo Guerrero hizo hincapié en el hecho de que llegaron al aeropuerto, sin duda alguna, por la mediación de Orula, el orixá vigilante de los destinos. (Wilson, Los nietos 27)

The college professor's knowledge is elevated by his awareness of the attributes of four of the orishas from the Yoruba Pantheon: Changó, the orisha of battle and thunder, Oyá the orisha of storms and establishing order, Elegguá, powerful orisha that controls the door to communication with all other orishas, and Orula, the orisha of divination.

Triunfu's wife Olivia is described as being a santera. When she first arrives to the airport, she is asked about the word sodinu: "Dudo que esa palabra sea lubumí -con marcado acento cubano dijo Olivia, una santera, y como su madre, sacerdotisa de Oko, orixá de la agricultura" (Wilson, Los nietos 31). In the Pantheon of Saints, orisha Oko works with agriculture, fertility and life. ${ }^{7}$ The fact that these individuals are described as being connected with Santeria, they are connected to a world that permits them to be more spiritually-centered compared to the Catholic Colonial Black characters. ${ }^{8}$

One of the novel's mis-educated Colonial Black comical characters is named Lesbiaquiña Petrablanche de las Nieves de Monte Monarca Moreno. ${ }^{9}$ When this devout Catholic woman learns of Ambrosio Lewis's appointment as the first Catholic priest of Afro-Antillean descent in Panama, she loses faith in the Catholic Church as well as the Pope, and concludes that the latter must be possessed by Satan. She feels that Lewis's ordination is inappropriate because of his Antillean heritage: La iglesia va de mal en peor. Ahora el Vaticano permite que un chombo sea sacerdote católico. ¡Ave María Purísima! ¿Por qué la iglesia no promulga leyes como la Constitución del 41? Los padres del sacerdote chombo son negros de inmigración prohibida porque su lengua materna no es el castellano y seguro que los abuelos del sacerdote chombo le rezaban a Obatalá, Yemayá y Changó. (Wilson, Los nietos 173).

Lesbiaquiña believes that, because his ancestors were not originally from Panama, he is unqualified to be a Catholic Church leader. Her reference to three of the major Afro-Caribbean orishas reflects her belief that the cultural practices be an indicator of their inferior status. She feels that the Church should move to exclude this sector of the population by supporting the Constitution of 1941 that prohibited the continued immigration and citizenship to nonSpanish speaking immigrants. According to the Constitution, Panamanian citizens were defined as: "Los nacidos bajo jurisdicción de la República, aunque uno de los padres fuera de inmigración prohibida, siempre que el otro sea panameño por nacimiento. Esta disposición no se aplicará cuando el padre que fuere de inmigración prohibida pertenezca a la raza cuya idioma originario no sea el Castellano" (Constitución de la República de Panamá, Panamá 1941). ${ }^{10}$ Lesbiaquiña's true fear is that this decision will make it easier for Panamanians, such as her niece, to marry Antillean Blacks.

Later in the novel, Lesbiaquiña Petrablanche de las Nieves de Monte Monarca Moreno becomes angry when she discovers that the Vatican has canonized Afro-Peruvian San Martín de Porres as a Saint. She is so upset that she renounces her membership of the Catholic Church to become Jewish:

Yo voy a renunciar mi catolicismo porque cómo es posible que el Vaticano permita que un chombo sea sacerdote católico. Ya esto es el colmo porque no cabe duda que pronto la chombada va a exigir que sea obispo. Sí, y para colmo de males, ahora van a tener a un santo católico. Yo no quiero ser miembro de una religión que permite estas barbaridades. Quiero ser judía desde hoy en adelante, judía. (Wilson, Los nietos 183)

Ironically, she fails to note that her decision to convert to Judaism would make her part of a cultural community that has also faced centuries of oppression and discrimination in the world — similar to Antillean Blacks in Panama. 
The community's obese mestizo priest named Padre Montebello is one of the few characters who completely agrees with Lesbiaquiña's attitudes. Throughout the novel, he repeats a declaration that underscores his disdain towards Antillean Blacks and Yoruba-inspired orishas: "Si yo fuera Díos, ningún negro iría al Cielo y mucho menos ese nieto de creyentes africanos en Obatalá, Yemayá y Changó” (Los nietos 199). ${ }^{11}$ The Priest believes that the Antillean population should not go to heaven because of their faith practices. The priest and Lesbiaquiña share many similar characteristics: Both have an affinity for consuming bat meat and are described as being involved in abnormal sexual behaviors by the narrator. Los nietos expresses cultural resistance by its inclusion of rituals that reflect African-influenced traditions.

Rituals within the novel's community allows believers to achieve what they desire, with the assistance of the orishas. Felicidad Dolores uses a ritual to mediate peace between her feuding neighbors. The griot figure lives between the Antillean Black character, John Brown, and Colonial Black character, Juan Moreno. Only the sage is able to allow the two men to understand that they share more commonalities than differences. As Juan Moreno and John Brown's tensions come to a dramatic show down; their favorite orishas respectively Changó and Ogún - protect each man:

Luego, más tarde en la víspera de la Epifanía, llamó la atención la llegada del vecino zapatero seguido por orixa Ogún, con una botella de ron en una mano y en la otra un machete. Pero, mayor fue el asombro cuando cinco minutos después, cuando perros y gatos callejeros comenzaron a pelear, entre truenos y relámpagos, llegó el vecino frutero seguido por orixa Changó, también con una botella de aguardiente y un machete. (147-148)

In Yoruba mythology, Ogún and Changó are eternal enemies because of their love for Oyá, Changós wife (González-Wippler 46). The presence of the spiritual forces of these orishas is underscored by the sound of thunder and lightning. The tension between the two men is mirrored in the natural world by the fighting between dogs and cats in the street beneath the sound of thunder and flashes of lightning. Felicidad Dolores attempts to decipher the messages sent to her by Elegguá, but is unable to understand them because of the loud vulgar comments from
Lesbiaquiña Petrablanche de las Nieves de Monte Monarca Moreno and others in the community who encourage the fruit vendor and cobbler to fight.

Felicidad Dolores places herself between the two men and orders her granddaughter to bring two glasses and she calms their anger by serving them tamarind chicha. ${ }^{12}$ She fills their glasses with the drink, cleans their faces, and instructs her daughters to place a black tortoise on the blade of each man's machete. Once the two tortoises have been placed on the blades, the men are no longer motivated to fight; they instead turn to playing a game of domino. The wife of the Italian bread maker interprets the amazing change of events as being witchcraft: "Esto es brujería" (Los nietos 151). Aníbal Brown, the cobbler's son, believes that it must be obeá; a term used in the West Indies to refer to folk magic, sorcery, and religious practices developed among West African slaves, specifically of Igbo origin. (152) Felicidad Dolores's ritual saves the men's lives and cannot be explained by Western reasoning, therefore it is equated with powers that belong to the world of the orishas. Once seated playing domino, the men discover that they have suffered some of the same abuses. Both men are descendants of Africa, symbolized by Felicidad Dolores.

The inclusion of the tortoise image is very significant because of its connection with PanAfrican folklore. Los nietos pays homage to the tortoise from popular folk-tales such as The Tortoise and the Hare. These didactic tales for children are built upon the crafty tortoise that wins when pitted against the fast-running and overconfident hare. This symbol is of particular importance to Cubena, as it is one of the images on his personal family crest that can be found in the front of the book. He describes this animal in the beginning of Los nietos as being analogous to blacks: "La tortuga simboliza el tipo de carácter que han desarrollado los de ascendencia africana durante su odisea por las Américas" (8). The tortoise, like the population of color in Los nietos, survives because of his wit and perseverance. The airport serves as a meeting space for all of the descendants of Africa, which are described as "las gentetortugas" or tortoise people (80).

After a lengthy delay, the plane is about to take off and the following description offers a glimpse of the manner in which the characters rejoice by giving thanks to the orishas: "Y, tras los cantos de alabanzas 
y gracias a Yemayá, Obatalá y Changó, los orixas de cabecera de las gentetortugas en el avión que volaba como un cóndor andino" (Los nietos 80 ). The proceeding quote reflects the family's connection with the orishas and is one of numerous quotes that reveal the image of the tortoise, known as jicotea in Lucumí. Throughout the novel, there is reference to the reptile, an animal that connects with African mythology and Pan-African culture.

The tortoise is an important symbol for the children of Africa:

Y, luego, al séptimo atardecer, Nana Olodumare invitó a los primeros africanos a poblar feliz y eternamente las fértiles orillas del río Nilo, dondo bajo la sombra de un robusto y frondoso baobab se encontraban tranquilamente un elefante, una cabra y una tortuga señal de que ese era el corazón del reino ancestral (Wilson, Los nietos 81).

In this African utopia, five young men plan to overthrow the noble leadership and the circle of elders. To counter this conspiracy, the mythical origin of different languages appears: "Pero, felizmente, la conspiración fraguada por los cinco jóvenes malvados frascasó cuando intevino orixa Elegguá, enviado por el orixa de la Adivinación y Sabiduría: Orula, confundiendo a los cinco conspiradores que, extrañamente, empezaron simultáneamente a comunicarse entre ellos en cinco lenguas, las cuales ellos mismos no entendían" (Wilson, Los nietos 82). After being expelled from their home in Africa, they must find a new paradise by the Nile under a large baobab tree and search for a tortoise under a tamarind tree.

The tortoise becomes the symbol that the cursed children of Africa must find in order to be forgiven by the orishas: "solamente serían perdonados los que a la cuna ancestral regresaran arrollados delante de sus progenitores, para pedir perdón por la grave ofensa a los nobles y sabios abuelos, luego a acariciar una tortuga negra que se encontraría cerca de un tamarindo a orilla de un río" (83). ${ }^{13}$ The tortoise image is combined with three of the orishas at the birth of Felicidad Dolores's triplets in the suburbs of Panama City:

Mientras más noche se hacía más llovía, purificando a ritmo de tambores el ambiente en los vecindarios de Malambo y Pierdevidas y, precisamente, como habían anunciado las tres ancianas africanas poco después de terminar la limpieza de la habitación que ocupaba la embarazada Felicidad Dolores y, también al cesar los cantos ceremoniales a Yemayá, Obatalá, Changó y los otros orixas, al nacer las tres tortugas negras de los huevos cubiertos con hojas de ceiba, tamarindo y baobab, nacieron simultáneamente las trillizas abrazadas, pregonando con entusiasmo, tres veces cada una, la palabra sodinu. (Wilson 113)

In addition to making a parallel between the simultaneous birth of the triplets and the tortoises, it also reflects ritualistic activity led by three elderly women that prepare for, and assist with, the birth. The three African women arrive to prepare the body after Felicidad Dolores' numerous deaths caused by major global events that attack populations of African ancestry. The women sing traditional songs dedicated to three of the major orishas.

The role of oral tradition is acknowledged throughout the novel. Richard Jackson recognizes this presence and makes a logical assumption that identifies the source of this technique: "Cubena is an effective storyteller, and much of the novel's originality derives from the author's refreshing willingness to unreservedly imbue his novel with a black perspective, one much influenced by the oral tales that he passes on that were first given to him by his old grani ('abuelita')" (Jackson, Black Literature 75). Within the novel the granny figure keeps the collective cultural memory alive in the mind of the African-descended characters. Felicidad Dolores serves as a griot figure, which according to Birmingham-Pokorny enables her to serve as the bridge that unifies the entire history of the African race ("La recuperación" 122).

In the airport scene, Felicidad Dolores uses her mastery of storytelling to entertain the youngsters in the terminal: "Tras breve pausa, llamó a varios niños para contarles las aventuras de 'El hermano araña' y otros cuentos. Luego, sacó a colación su tema favorito: Bandelé Cebiano" (Wilson, Los nietos 41). In addition to entertaining the future generations, her stories provide lessons about their own culture and history. Through these intercalated tales, myth is brought to the forefront and shared with the hope that they will instruct the younger generation and to carry on the tradition. As the griot shares her tales in the airport, only the astute Antillean Blacks are able to benefit from her wealth of oral history. The characters who 
best recognize the importance of the matriarch's tales are the educated and well-traveled family members:

No obstante, casi todos los chombos, pichones y cocolos, sobre todo los que habían viajado y estudiado, admiraban el hecho de que la señora Felicidad Dolores, una analfabeta, supiera 'tan detalladamente - se comentaba año tras año - lo de los nobles faraones nubienses y las pirámides de Egipto en Africa; los poderosos reyes africanos en Ghana, Mali y Songhay; los esclavos negros en Sevilla durante la época de los Reyes Católicos; las hazañas de los africanos en Santo Domingo, Tenochtitlán y Cuzco; el heroísmo de los caciques cimarrones Yanga, Cudjoe, Benkos, Zumbi, Coba, Zabeth, Bayano. (Wilson, Los nietos 24)

The characters who listen to her tales are able to piece together events from their ancestral past and apply them to their present reality. As a result of hearing these tales, the characters can learn who they are and from where they come.

Another character who serves as a griot is Felicidad Dolores's second child, Guacayarima. Guacayarima's oral tales play an important role in entertaining and teaching slaves during the Mexican Colonial era about the Yoruba creation myth: "Los domingos cuando descansaban los esclavos africanos, Guacayarima era muy solicitado también para que tocara la marimba y para que narrara lo que sabía de los primeros africanos creados en las cumbres del Kilimanjaro" (Wilson, Los nietos 97). For the illiterate slaves, storytelling was a way to escape from the difficulties of their oppressive lives. At the same time, they learn about their shared ancestral past. He shares the same tails that he learned from his mother Felicidad Dolores. Through these tails, the reader becomes the audience and learns about the history of descendants of slaves. African mythology is used to explain the origin of different ethnic groups.

Mythical tales serve as the novel's foundation and allows the work to link the living characters with their ancestors. Throughout the novel, there are intercalated references to Africa's past. For example, an unidentified narrator makes reference to the heights of Kilimanjaro, the legendary location where the children of the Olodumare were first created. Within this environment, reminiscent of the Biblical Garden of Eden, the population lived in a safe and harmonious existence. This point of perfect existence was destroyed when five African youths attempted to overthrow the elders:

. . . bajo un robusto y frondoso baobab a orilla del río Nilo... el principio de una gran maldición vinculada con un ombligo de mal agüero y una odisea apocalíptica que se complicó a orilla del río Níger bajo un tamarindo en el corazón de Buruco, de donde zarparon los navíos negreros rumbo a tierras madrastras de felicidad y dolores (Wilson, Los nietos 228-229)

Omolú's anger against the African youth, exiles them from this locus amoenus under the protection of the baobab tree. The use of the name Orixa Omolú (Babalú-Ayé in Lucumí) acknowledges one of the major saints in another African-inspired faith tradition known as Candomblé in Brazil.

After being expelled, the five Africans must locate a second tranquil paradise under the protection of a tamarind tree described by the elders of the fictitious town of Nokoró:

Por fin, después de mucho deambular, madrugadas tras madrugadas, desde el río Niho al río Zambeze y, luego, desde el río Congo al río Níger, encontramos el lugar indicado por el concilio de nobles y sabios abuelos a orilla de río Níger, donde con gran júbilo nos establicimos en Buruco. Allí ...los animales ahora eran más feroces y numerosos leprosos nos codeaban (Wilson, Los nietos 83).

In the new town of Buruco, the population has the potential to gain atonement as newer generations remember their past. The failure to remember the past is a cosmic error, which causes the children of Buruco to be expelled. This expulsion is to the Americas as slaves in a foreign land filled with danger as their punishment. They are promised redemption only when they become unified and remember their collective past. The author uses this mythical beginning to explain the slave trade.

Within the novel, the origin of different races is based on West African mythology. The narrator explains that the mighty creator Olodumare caused the evil rebel leader Kwafufo to lose his black pigment as a punishment for his leadership in the attack against the leaders in the town of Nokoró. This creation of the white race appears in the first chapter as Elsa reveals the myth to those present: 
¿Acaso no se dan cuenta de su vergonzoso origen? Pues, por la carencia de melanina en su piel es palpable que son descendientes de la demente e incestuosa prole albina del malvado Kwafufo, el que por irrespeto a los ancianos, como maldición, perdió la bella negrura de su piel desde tiempos remotos allá en Nokoró, el antiguo pueblo africano a orillas del río Níger que fundó la familia Onítefo. (Los nietos 56)

This myth demonstrates how the novel reverses the concept of blackness by offering a mythical version that sees whiteness as a punishment. This mythical explanation counters the biblical interpretations that have concluded that black ethnicity was a punishment by the Judeo-Christian God against Ham for looking upon his father's nakedness:

And Noah began to be a man of the soil, and he planted a vineyard. He drank of the wine, and became drunk and lay uncovered in his tent. And Ham, the father of Canaan, saw the nakedness of his father and told his two brothers outside. Them Shem and Japheth took a garment, laid it on both their shoulders, and walked backward and covered the nakedness of their father. Their faces were turned backward, and they did not see their father's nakedness. When Noah awoke from his wine and knew what his youngest son had done to him he said, 'Cursed be Canaan; a servant of servants shall he be to his brothers.' He also said 'Blessed be the Lord, the God of Shem; and let Canaan be his servant. May God shall enlarge Japheth, and let him dwell in the tents of Shem, and let Canaan be his servant (Genesis 9:20-27).

The following passages from the book of Genesis have been used by biblical scholars to justify the enslavement of Africans by Europeans. According to historian Drake such interpretations come from the Babylonian Talmud and the Midrash, collections of Biblical interpretations based on legends and myths (2-76). It is this logic that has historically justified whites' negative treatment of blacks.

In the novel, when the narrator describes the adventures of Guacayarima and his voyage to the Americas, a European priest who baptizes the surviving slaves aboard the ship uses Aristotilian philosophy and the biblical myth to explain the slaves' resistance to baptism: "Además, consideraba a todos los africanos pecadores polígamos y descendientes asquerosos de Canaan, malditos por el mismo Noé, a quienes era justo conquistar en Buena Guerra para esclavizarlos como castigo por la dominación mulsumana en España" (Wilson, Los nietos 109). The novel makes reference to the belief that Noah's curse on his son Ham and his descendants was the cause of the inferior role of the individual of African heritage. Religious interpretation is one of the most common ways to attack other groups that are seen as inferior.

As the novel ends, the mystery of the word sodinu is revealed when one of Felicidad Dolores's grandsons, Policarpio Reid writes a letter to his daughter and explains the following: "...la clave de la palabra esa que te intriga, pues escribe la palabra en letras de molde negro y colócate delante de un espejo y mira la palabra en el espejo y lee lo escrito de izquierda a derecha. Esa es la clave de nuestra salvación" (Wilson, Los nietos 230). The concept of unity among all the children of Felicidad Dolores, in the African Diaspora, will lead to a strong sense of community and collective progress.

This study has attempted to focus on the manner that Los nietos de Felicidad Dolores highlights an Africaninspired aesthetic by way of African myths and orishas. The novel also presents images that are important within the Caribbean. The word jicotea (tortoise) serves as a metaphor of the descendants of Africa throughout the Diaspora. Los nietos also serves as a literary weapon to reveal complex issues that face individuals of African ancestry in the Americas. The work has a structural form that is consistent with African-influenced values and aesthetic. The matriarch Felicidad Dolores is described as the spiritual mother of enslaved African peoples. The Antillean community is presented as being intimately connected with African-centered faith practices.

Los nietos de Felicidad Dolores serves as an example of Ashé-Diasporan literature. The inclusion of elements of non-Western tropes and images allow the novel to project a magical world. Cubena's inclusion of these elements makes him one of many revolutionary writers that use their literature to reclaim African-influenced spiritual culture. Cubena is one of numerous Caribbean writers such as Alejo Carpentier, Manuael Zapata Olivella, Quince Duncan, Nicolás Guillén, and Nancy Morejón who have used their creative talent to present the historical, cultural and spiritual realities that reflect this Panamanian form of Ashé-Diasporan 
literature to spark social change as posited by Frantz Fanon.

Cubena redefines the Antillean Black population, which traditionally has been denigrated in Panama. This is a wretched revelation in light of the significant contributions they have made in creating the nation's infrastructure. Despite decades of legal and social attempts to control and eradicate West Indian identity, elements of this population survived in the collective memory of Africans and their descendants in the twenty-first century.

\section{Dr. Thomas Wayne Edison University of Louisville}

\section{Bibliography}

1941. Constitución de la República de Panamá. Panamá. Print.

Arroyo, Justo. 1995. Race Relations in Panama. In African Presence in the Americas, ed. Carlos Moore. New Jersey: Africa World Press. Print.

Birmingham-Pokorny, Elba and Elba Doris. "Interview with Dr. Carlos Guillermo Wilson." Confluencia: Revista Hispánica de Cultura y Literatura 6.2 (1991): 127-33. Print.

---. "La recuperación del pasado histórico y la reafirmación de la identidad Afro-Panameño en Los nietos de Felicidad Dolores." Denouncement and Reaffirmation of The Afro-Hispanic Identity in Carlos Guillermo Wilson's Works, ed. Elba Birmingham-Pokorny:129-137. Miami: Ediciones Universal, 1993. Print.

Brandon, George. Santeria from Africa to the New World: The Dead Sell Memories. Bloomington 1993: Indiana UP, 1993. Print.

Cabrera, Lydia. El monte, igbo finda, ewe ori. Havana: Burgay y Cía, 1954. Print.

Drake, St. Clair. Black Folks Here and There. Diasporic Africa Press, 2014.

Edison, Thomas Wayne. "Humor and Satire: Ammunition in Carlos Guillermo Wilson's Resistance Novel Chombo," College Language Association Journal 43.4 (2000): 494-511. Print.

Fanon, Frantz. Black Skin, White Masks. New York: Grove Weidenfeld, 1967. Print.
---. The Wretched of this Earth. New York: Grove Weidenfeld, 1963. Print.

Freire, Paulo. Pedagogy of the Oppressed. New York: Continuum, 1997. Print.

González-Wippler. Santeria: African Magic in Latin America. New York: Julian Press, 1973. Print.

---. Santería the Religion. St. Paul: Llewellyn, 1994. Print.

Jackson, Richard L. Black Literature and Humanism in Latin America. University of Georgia Press, 2008. Print.

Ócha'ni Lele. The Secrets of Afro-Cuban Divination: How to Cast the Diloggun the Oracle of the Orishas. Destiny Books, 2000. Print.

Olmos, Margarite Fernández. Sacred Possessions: Vodou, Santeria, Obeah, and the Caribbean. Rutgers University Press, 1997. Print.

Soley, Laverne M. Seals. "Entrevista con Carlos Guillermo 'Cubena' Wilson.” Afro-Hispanic Review 17.2 (1998): 67-69. Print.

Vega, Marta Moreno. “'The Ancestral Sacred Creative Impulse of Africa and the African Diaspora: Ase, the Nexus of the Black Global Aesthetic." Lenox Avenue: A Journal of Interarts Inquiry 5 (1999): 45-57. Print.

Watson, Sonja Stephenson. The Politics of Race in Panama: Afro-Hispanic and West Indian Literary Discourses of Contention. Gainesville, Florida: University Press of Florida, 2014. Print.

Wilson, Carlos Guillermo. Chombo. Colección Caniquil. Miami: Ediciones Universales, 1981.

---. Los nietos de Felicidad Dolores. Miami: Ediciones Universal, 1991. Print.

---. "The Role of Afro-Latino Writer and the Quincentenary (1492-1992)." Afro-Hispanic Review 10.3 (1991): 67-71. Print.

---. "Unpublished autobiography." 1994. Print.

Woodson, Carter G. The Mis-Education of the Negro. Trenton: African World P, 1990. Print.

Wynter, Sylvia. "We Must Learn to Sit Down together and talk a Little Culture." Jamaica Journal 2.4 (1968): 21-32. Print. 


\section{Endnotes}

${ }^{1}$ The griot is a member of a hereditary caste among the peoples of western Africa whose function is to keep an oral history of the tribe or village and to entertain with stories, poems, songs, dances, etc. These respected individuals are historians, storytellers, poets and/or musicians.

${ }^{2}$ When I started my research on Cubena's work, I established contact with him and he sent me a thirtythree page document that provides information about himself, his family and their connection with the construction of the canal. He also explains why he writes.

${ }^{3}$ In Cuba, one well-known rebel leader was Carlota (????-1844). She was one of three leaders who organized a slave revolt at the Triumvirato sugar mill in Mantanzas, Cuba by using the drum to communicate. There are other vivid examples of resistance activities being led by spiritual leaders in other parts of the Americas: Zumbi in Brazil (1655-1695); Jamaica's major leaders include Cudjoe (1680-1744), Nanny (1685 - circa 1755), and Tacky (????-????). One of Mexico's most famous rebel leaders was Yangá (circa 1545- circa 1631), and in the early United States with leaders such as Harriet Tubman (1820-1913). All these resistance leaders used elements of spirituality to unify the oppressed to achieve dramatic social change. Tacky led Ashanti slaves in an event that would be known as Tacky's War or Tacky's Rebellion. Tacky sought to legitimize his position by securing the services of an Obeahman as a magio-religious co-leader charged with supplying the rebellious slaves with a potion that would make them invulnerable in battle. The defiant slaves came to believe that Tacky could catch any bullet aimed at him and fire it back at the enemy (Olmos, 8).

${ }^{4}$ Vodún is a sister religion of Santería being made up of the mixture of Dahomey spiritual practices that were practiced by the Ewe people of southern Ghana and southern and central Togo, the Mina and the Fon people of southern and central Togo and southern and central Benin.

${ }^{5}$ King Louis XIV, of France, implemented the Code Noir or the Black Code in Haiti in 1685 for the regulation of the slave trade to restrict activities of slaves.
${ }^{6}$ Lucumí is the term used to describe a transcultural spiritual practice that emerged when distinct African practices combined with elements of Christianity in Cuba.

${ }^{7}$ Oko is often depicted as a hard-working farmer who wears a straw hat and plows the earth with a team of oxen.

${ }^{8}$ The writer uses contrived names to reflect the nature of the characters in Chombo.

${ }^{9}$ This term is borrowed from Carter G. Woodson's The Mis-education of the Negro (1933). The miseducated Negro has internalized negative attitudes toward fellow Blacks. Therefore, they play no role in improving the situation for the race as a whole.

${ }^{10}$ The Constitution of 1941 made such an impact on the lives of Antilleans that reference to it, especially Law 13, appears more than a dozen times on the following pages $(58,70,127,129,130,131,132,133,157$, $158,162,168,170,173,176,205,206)$.

${ }^{11}$ This statement is repeated on pages 174 and 175.

${ }^{12}$ In Panama, this drink is like a fruit drink. In some regions it is fermented.

${ }^{13}$ The tortoise image found under the tamarind tree appears repeatedly throughout the novel on the following pages $56,81,23,41,81,82,83,93,95,128,131,1$ 34,147,193, 202,226,228. 
